\title{
„And What is a Beautiful Poem”? \\ Reflections of a Poet on Vlad Petre Glăveanu's \\ The Psychology of Creativity: A Critical Reading
}

\author{
Katarzyna Citko \\ University of Bialystok, Poland \\ E-mail address: k.citko@uwb.edu.pl
}

\section{ARTICLE INFO}

\section{Keywords:}

Poetry

Inspiration

Metaphor

Transcendence

Mystery

\section{Article history:}

Received 3 November 2014

Received in revised form 2 December 2014

Accepted 15 December 2014

\section{A B STRACT}

ISSN: 2354-0036

DOI: $10.1515 /$ ctra-2015-0015

Vlad Petre Glăveanu's article gets to the heart of issues related to attempts to describe the phenomenon of creativity from the standpoint of the psychology of creativity. Indeed, this field of study has seen major interest from researchers in recent years, and yet it is characterized by considerable chaos and confusion in the approaches, methodologies and issues raised by the research in this area.

Glăveanu observes that in the case of the psychology of creativity, just as in the case of all other disciplines, the need for scientific research is an important requirement. At the same time, however, in the six inspiring postulates laid out in the summary of his deliberations, he urges us to revise old habits. In his opinion, one should abandon traditional methods and measures of analysis, be critical of generally recognized definitions and theories, ask original questions, build new theories and think about practical conclusions and proposals. Psychometric tests, in particular, should be approached with extreme caution, for any attempt to quantify creativity always runs the risk of reductionism and simplification. 
I fully subscribe to those of Glăveanu's opinions mentioned above. I am not a psychologist, but as someone who specialises in culture and at the same time as a poet, I believe that if the psychology of creativity is to say something truthful about the creative process, it should open up to the inner life of artists and to statistically immeasurable processes such as talent and inspiration, rather than devise and carry out laboratory experiments. For such an approach brings to mind Stanislaw Lem's story of Trurl, who attempts to construct a machine to construct ... Trurl (Lem, 1964). Standardization and normalization are not suitable methods for describing phenomena which are fundamentally nonnormative. Creativity conceptualised as a value on a scale from zero to $x$ cannot be regarded as a measure of the level of artistic activity. One should decidedly reject the misconception that things exist only if they can be measured and classified.

Therefore, encouraged by Glăveanu to pose innovative questions, I would like to ask about the essence of poetic inspiration, that is able to create images and lies at the root of metaphor which emerges in the mind of an artist.

In order to answer the question, one should definitely go beyond the rigid framework of scientific knowledge. For this reason, sharing Glăveanu's doubts concerning the psychology of creativity, I am even more sceptical than the author of the article. For I wonder whether scientific investigation can ever say anything significant about the phenomenon of creativity and I mean especially, those areas of science which claim that something exists, as long as it has been measured and that the more accurate the measure, the better it can be understood. Such ontology is perhaps accurate, but certainly deficient and flat. Ken Wilber calls this type of research "systems theory" (or "flatland holism") and stresses that it is completely devoid of anything that might resemble beauty, value, love, compassion, God, Eros or Agape, artistic expression or poetry (Wilber, 1998, p. 67). Gaston Bachelard would add at this point, that the tracks along which science and poetry run, go in two different directions (Bachelard, 1975). Not only is poetry the external image of the internal experience of the world by a subjective entity, but poetry is ontogenesis, because it explains the world in its complete and original spectrum of existence. Poetic discourse is born, as it were, by itself. It emerges from non-existence, spontaneously and often in an unplanned way. So how can one capture and describe the ontology of poetic images, their hierarchy and network of interconnections and metaphorical strands? Such questions seem to be beyond the reach of psychology. Bachelard emphasizes that poetic imagination, employing the metaphor of metaphor, creates a sphere of the indigenous and autogenous and escapes the definitions of psychology, including those of psychoanalysis (Bachelard, 1975, p. 58). 
Raïssa Maritain in her essay "Poetry as Spiritual Experience" (Maritain, 2012) states that the source of poetry, as any other creative inspiration, is the result of contact of the spirit with an inexpressible reality whose source is in God. But even if poetry is not theology: "It is, in any case, ontology because, if true, it is born at the mysterious source of being. There poetic cognition is established and the poet connects with a particular dimension of things. The cognition is essential and poetry is a song about it. The cognition is realized by considering the features of the subject which led to it. It is concrete and specific. It is so internal, penetrating, and profound that it strikes at the heart of the poet, which is already tuned and ready to sing a song of revelation like a sleeping lark, which, awoken by the sun, flies up to the sky and sings" (Maritain, 2012, p. 222).

Creative focus understood as, entrance into oneself, is the gift of inspiration and is given to the poet in statu nascendi, without his having strived to merit it; it is his natural disposition which he should develop by delving into his soul. Certainly, an excellent or creative artist is not one who at all costs, seeks only novelty in his work. Paradoxically, striving for originality may be a sure way of adopting an affected style; Maritain stresses that such poets are miserable craftsmen: they only know what they are doing - their emotions, their idea of the work, their ways of expression. Whereas the real poets, like Baudelaire or Rimbaud, are aware of their state of being, torn between matter and spirit, body and soul, and yet they remain humble in the face of reality, which is the source of their inspiration, but which at the same time, surpasses them. Similarly to Maritain, Bachelard also observes that in the second half of the nineteenth century, there were only three poets who created original schools of writing, without even realizing it: Lautréamont, Rimbaud and Baudelaire. Their work was unrivalled but in no way did they try to comment on it, explain it or give it a judgment of reason. Since the inexpressible aspect of reality is impossible to identify or classify: "It is so soon that what we had to say gives way to what, to our own surprise, we write that it is hard not to feel how far the written word creates its own world. The world of words ordered on a white sheet producing organization of images is often governed by different laws but always obeys the great laws of imagination" (Bachelard, 1975, p. 215).

In this context, Mieczysław Kucner rightly observes that poetry is a leap from finiteness to infinity, the suspension of rationality for the sake of "immersion in the darkness of the incomprehensible" (Kucner, 1980, p. 181).

Relying only on rationality leads to a disregard of what is the most important in men: "Rational light is a subjective one; it is one-sided, incomplete, and yet it claims the right to completeness and exclusiveness, thus it quickly changes into falsehood and treach- 
ery" (Kucner, 1980, p. 180). Darkness, as a characteristic feature of poetic vision, opens the gate to understanding of what constitutes the essence of humanity. It is not only what is visible, but also what is invisible and spiritual: “(...) darkness, chiaroscuro is a truly human way, like birth and death, hope and promise - the infinity of the finite" (Kucner, 1980, p. 181).

Rational consciousness is not the only way to discover and describe the world available to men; especially because it remains blind to some aspects of reality. Ken Wilber rightly observes: "There is a strange and curious thing about scientific truth. As its own proponents constantly explain, science is basically value-free. It tells us what is, not what should be or ought to be. An electron isn't good or bad, it just is; the cell's nucleus is not good or bad, it just is; a solar system isn't good or bad, it just is. Consequently, science, in elucidating or describing these basic facts about the universe, has virtually nothing to tell us about good and bad, wise and unwise, desirable and undesirable. (...) Truth, not wisdom or value or worth, is the province of science" (Wilber, 1998, p. 10). The ultimate ways to explore the world belong to poetry or art in general.

The source of poetry does not lie in a rational world view and cannot be investigated by means of rational tools. It is, by its nature, mysterious and open to transcendence. The poet goes beyond the limits of reason, as he experiences existence, including all forms of being, as a spiritual process. His imagination lets him sense not only the material world, but also the spiritual one, and to see far into the distance and beyond. The poet is one who decides to live on the other side of existence. Undoubtedly, his oversensitive nature makes him see in a different way and more than ordinary people. He certainly is a misfit, marked by the stigma of personal dissection or perhaps even a touch of madness which is expressed through the fervour and euphoria of creating poetic metaphors.

"And what is a beautiful poem, if not a little dressed up madness? A touch of poetic order imposed on frantic images? An intelligent moderation which prevents the abuse of imagination-induced drugs. Life is driven by dreams - insane dreams” (Bachelard, 1975, p. 413).

The imagination of the poet, the twists and turns of his creative thinking, do not easily lend themselves to scientific descriptions. They are a mystery, both in relation to the process of creating a poem, as well as its sources. Regardless of what the psychology of creativity determines about the phenomenon of poetic experience, how it will attempt to define and estimate it, every true poet is doomed to create. Even if he is constantly accompanied by a desperate conviction of the absolute impossibility of expressing the depths of the spirit, even to some small extent: „A sponge, suffering because it cannot saturate itself; a river, suffering because reflections of clouds and trees are not clouds and trees" (Milosz,1988, p. 435). 


\section{REFERENCES}

Bachelard, G. (1975). Wyobraznia poetycka. Wybor i przeł. Chudak H. Warszawa: PIW.

Glăveanu, V.P. (2014). The Psychology of Creativity: A Critical Reading. Creativity. Theories - Research - Applications, 1, 1, 10 - 32; DOI: 10.15290/ctra.2014.01.01.02.

Kucner, M. (1980). Egzystencja i kreacja. Lodz: Wydawnictwo Lodzkie.

Lem, S. (1964). Bajki robotow. Warszawa: Wydawnictwo Literackie.

Maritain, R. (2012). Dziennik. Przeł. Zurawska M. Warszawa: Biblioteka „Wiezi”.

Milosz, Cz. (1988). Poezje. Warszawa: Czytelnik.

Wilber, K. (2008). Malzenstwo rozumu z dusza. Integracja nauki i religii. Przeklad: Smagacz H. Warszawa: Jacek Santorski \& Co Agencja Wydawnicza.

Corresponding author at: Katarzyna Citko, Faculty of Pedagogy and Psychology, University of Bialystok, 20 Swierkowa St., 15328 Bialystok, Poland

E-mail: k.citko@uwb.edu.pl 